\title{
Optimization of Process Parameters by Statistical Experimental Design for Production of A- mannosidase From Moss Hyophilla Nymaniana (Fleish.) Menzel
}

\section{Rashmi Mishra ( $\square$ mishra.rashmibmg@gmail.com )}

Indian Institute of Natural Resins and Gums https://orcid.org/0000-0003-1845-4804

Ramesh Chandra

Professor

\section{Research}

Keywords: Taguchi, Design of Experiment, Hyophilla nymaniana (Fleish.) Menzel, Analysis of variance, alpha-mannosidase

Posted Date: November 18th, 2020

DOI: https://doi.org/10.21203/rs.3.rs-107268/v1

License: (c) (1) This work is licensed under a Creative Commons Attribution 4.0 International License. Read Full License 


\section{Abstract}

Alpha mannosidases are enzymes with varied applications preferably used in the preparation of important compounds of food and pharmaceutical industries. The production of enzymes is influenced by medium compositions as some of the constituents of the medium directly affect the enzyme synthesis. In the present study, the components of the culture medium are optimized by classical and Taguchi method for a-mannosidase from the suspension culture of the moss Hyophilla nymaniana (Fleish.) Menzel. One factor at a time approach was used in the preliminary screening of factors before proceeding optimization studies. Implementation of Taguchi Design of Experiment generated 16 experimental runs based on five factors sugar, temperature, $\mathrm{pH}, \mathrm{rpm}$, and nitrogen source. Analysis of variance (ANOVA) was performed on the obtained results and the optimum condition suggested by statistical calculations was validated in a verification test. The ANOVA result showed that the $\mathrm{NH}_{4} \mathrm{NO}_{3}$ contributed maximum on mannosidase production followed by temperature and RPM. Predicted results showed an enhanced mannosidase $(63 \%)$ can be achieved with $\mathrm{pH} 5.8$, temperature $26^{\circ} \mathrm{C}$, RPM 120 , maltose $1.5 \%$, and $\mathrm{NH}_{4} \mathrm{NO}_{3} 2 \%$ as carbon and nitrogen source, respectively.

\section{Introduction}

a-Mannosidases (EC3.2.1.24), are an important N-glycosylation enzymes involved in both maturation and the degradation of Asn-linked oligosaccharides . These enzymes are an abundant constituent of plant hydrolytic system (Forse et al., 1989; Hossain et al., 2010). They are found in vacuoles and presumed to be involved in catabolism and turnover of N-linked glycoproteins (Pastuszak et al., 1990; Woo and Kimura; 2005). These a-mannosidase are commercially attractive due to its potential usefulness in food and pharmaceutical industries. They are used for production of fruit juices, degradation of plant material (Christgau et al., 1994) and for the manufacture of oligosaccharides (Akino et al., 1988). In addition, increased mannosidase level associated with seed germination and fruits ripening process (Chin et al., 1999). Defective a-mannosidase or deficient (AMA) activity is associated with a-mannosidosis (Sun and Wofe., 2001). In view of the involvement of the enzyme in various applications, its higher production is desirable. Recent, In vitro culture studies reveals the importance of bryophytes in biopharmaceuticals industries. Studies conducted on suspension culture of mosses have gain momentum as they share similarities with the protein $\mathrm{N}$-glycosylation patterns with the higher plants and possess an exceptionally high rate of homologous recombination in mitotic cells. Thus, making it a highly preferred system for the humanization of the glycosylation pattern through homologous recombination (Hohe and Reski., 2002; Decker and Reski., 2008). Despite of these advantages in vitro studies of bryophytes are still neglected topic. Although a number of the culture studies of bryophyte taxa are administered within the past regarding to nutritional requirement (Basile, 1975), spore germination, sporeling and regeneration studies protonemal morphogenesis but only a little work has been done in cultivating bryophytes in order to make them available in bulk amount for their potential use or further bioprospecting studies till date . Although, occurrence of a-mannosidase is frequently studied in bacteria, fungi, animals, and plants. But, a-mannosidase from suspension culture of mosses is still a neglected topic. The present study, gives a 
detailed description of establishment of suspension culture system for a-mannosidase production from moss Hyophilla nymaniana. Process parameters like sugar, temperature, $\mathrm{pH}, \mathrm{rpm}$, and nitrogen source which plays important role in effective enzyme production are optimized. First conventional one variable at a time approach (OVAT) was applied for the screening of all the factor and later Taguchi design of experiment was applied to optimize the process parameters that bring maximum enzyme production in the suspension culture system.

The conventional optimization process based on OVAT is a shotgun approach where each parameter is considered to be insensitive to the other process variables. This conventional method of medium optimization is highly cumbersome, time-consuming, requiring larger data sets or experimental trial conditions, and does not provide information of the mutual interactions between the factors' (Beg, 2003; Rao et al., 2004, Das Mohapatra; 2009). On the contrary, statistical design of experiments helps to investigate the interaction among variables with the least number of experiments (Basak et al. 2013a, b; Kennedy and Krouse 1999). The application of Taguchi methodology to optimize various process parameters in biochemical processes is well documented in literature. Taguchi's optimization technique is a unique and powerful optimization method that helps the researchers to establish the relationship between the variables of the medium components and to optimize their concentration in a different phase (Prasad et al., 2005). Although, Taguchi DOE has been used successfully to enhance production of different biomolecules by using a different orthogonal array, but till date, no reports are available for the production of a-mannosidase by this method. In this study, the components of the medium are optimized by the conventional OFAT approach and later optimum level of each parameter was optimized by Taguchi design of experiments to maximize the enzyme production from moss $H$. nymaniana.

\section{Experimental}

\section{Culture initiation}

Fresh unopened, mature capsules of $H$. nymaniana were taken for culture initiation. Capsules were surface sterilized with $2 \%$ sodium hypochlorite solution (w/v) for 5 minutes, washed 3 times with sterile distilled water. Spores in the capsules were aseptically transferred in hormones free MS medium at $25^{\circ} \mathrm{C}$ and with photon flux density of $18 \mathrm{Imol} / \mathrm{m}^{2} / \mathrm{s}$ with $16: 8$-h light-dark photoperiod. The young protonema cells developed from aseptic spores were taken for establishment of suspension culture.

\section{Cultivation of the plant in suspension culture}

A $250 \mathrm{ml}$ Erlenmeyer flasks containing $50 \mathrm{ml}$ MS medium was inoculated with 4 to 6 weeks old actively growing protonemal cells incubated at temperature $\left(22^{\circ} \mathrm{C}\right)$ on a rotary shaker set at $120 \mathrm{rpm}$ for 42 days. The seed medium was composed of $\mathrm{NH}_{4} \mathrm{NO}_{3}, 1,650 ; \mathrm{KNO}_{3}, 1,900 ; \mathrm{CaCl}_{2} .2 \mathrm{H}_{2} \mathrm{O}, 440 ; \mathrm{MgSO}_{4} .7 \mathrm{H}_{2} \mathrm{O}, 370$; $\mathrm{KH}_{2} \mathrm{PO}_{4}, 216 ; \mathrm{KI}, 0.83 ; \mathrm{H}_{3} \mathrm{BO}_{3}, 6.2 ; \mathrm{MnSO}_{4} .4 \mathrm{H}_{2} \mathrm{O}, 22.3 ; \mathrm{ZnSO} .7 \mathrm{H}_{2} \mathrm{O}, 8.6 ; \mathrm{Na}_{2} \mathrm{Mo}^{-\mathrm{O}_{4}} .2 \mathrm{H}_{2} \mathrm{O}, 0.5 ; \mathrm{CuSO}_{4} .5 \mathrm{H}_{2} \mathrm{O}$, 0.05; $\mathrm{CoCl}_{2} .6 \mathrm{H}_{2} \mathrm{O}, 0.05 ; \mathrm{FeSO}_{4} .7 \mathrm{H}_{2} \mathrm{O}, 26 ; \mathrm{Na}_{2}$ EDTA. $2 \mathrm{H}_{2} \mathrm{O}$, 37.3; myo-inositol, 90; nicotinic acid, 1;

pyridoxine $\mathrm{HCl}, 0.5$; thiamine- $\mathrm{HCl}, 1$; biotin, 0.01 ; glucose, 20,000 . Cells were sub-cultured every 3 weeks at 
$25^{\circ} \mathrm{C}$ and with photon flux density of $18 \mathrm{Imol} / \mathrm{m}^{2} / \mathrm{s}$ with $16: 8$-h light-dark photoperiod. $10 \mathrm{mg}$ of fastgrowing cells were suspended in $50 \mathrm{~mL}$ medium in $250 \mathrm{~mL}$ conical flasks and cultured on a rotary shaker (120 rev/min) at $22^{\circ} \mathrm{C}$ under illumination by fluorescent lamps using a 16:8-h light-dark photo-period.

\section{Extraction of crude enzyme}

The cells in the suspension culture incubated for different time intervals $(7,14,2128,35$ and 42 days) and were checked for the biomass production. Crude enzyme extraction (28-days-old culture) carried out from the suspension culture by centrifugation at $10,000 \mathrm{~g}$ for $10 \mathrm{~min}$ at $4{ }^{\circ} \mathrm{C}$. The cells were resuspended in phosphate buffer $(10 \mathrm{ml})$ containing $10 \mathrm{mM}$ beta mercaptoethanol and subjected to sonication at an amplitude of $35 \% 15,000 \mathrm{~J}$ energy and a pulse rate of $10 \mathrm{~s}$ on and $10 \mathrm{~s}$ off for $10 \mathrm{~min}$ at $4{ }^{\circ} \mathrm{C}$ The cells free supernatant used as a crude enzyme to perform enzyme assay.

\section{a-Mannosidase Assayand Protein estimation}

The activity of mannosidase was studied using the method of Kestwal and Bhinde (2005) with some modifications. $100 \mu \mathrm{l}$ enzyme solutions was added to $200 \mu \mathrm{l}(10 \mathrm{mM})$ of the substrate ( $p$-nitrophenyl-a-Dmannopyranoside) dissolved in $200 \mu$ citrate buffers $(100 \mathrm{mM}, \mathrm{pH} 4.5)$. The assay mixtures were incubated for $30 \mathrm{~min}$ and the reaction was terminated by the addition of $1 \mathrm{ml}$ borate buffer $(0.1 \mathrm{M}, \mathrm{pH}$ 9.5). Liberated $p$-nitrophenol was measured spectrophotometrically at $405 \mathrm{~nm}$. The total protein concentration was determined by the method of Lowry et al., 1951 using bovine serum albumin as the standard.

\section{Optimization of culture condition for mannosidase production}

Various process parameters that influence a-manosidase production were evaluated using the basal MS medium. Enzyme production was carried out in $250 \mathrm{ml}$ Erlenmeyer flasks containing $50 \mathrm{ml}$ medium with $10 \mathrm{mg}$ protonemal biomass. All experiments were performed in triplicates, and the results were reported as the mean of these replications.

\section{Optimization of the incubation period}

For the determination of protonemal biomass, $10 \mathrm{mg}$ of protonema biomass of $H$. nymaniana was inoculated in $250 \mathrm{ml}$ Erlenmeyer flasks containing $50 \mathrm{ml} \mathrm{MS}$ medium (pH 5.8). Each culture was incubated at temperature $\left(22^{\circ} \mathrm{C}\right)$ on a rotary shaker set at $120 \mathrm{rpm}$ for 42 days. The sample was harvested at 7-day intervals and production of protonemal biomasses was measured. Samples were withdrawn at a 7-day interval and centrifuged at $10,000 \mathrm{rpm}$ for $15 \mathrm{~min}$ at $4{ }^{\circ} \mathrm{C}$. The supernatants were assayed for a-manosidase activity.

\section{Optimization of the initial pH}

Effect of $\mathrm{pH}$ on production medium on mannosidase production was assessed by growing $H$. nymaniana in a medium of varying $\mathrm{pH}$ range $(4,4.5,5,5.5,6.0,6.5$ and 7.0$)$ at $22^{\circ} \mathrm{C}$. Samples were withdrawn from 
28-days-old culture to check the enzyme activity.

\section{Optimization of incubation temperature}

The optimal temperature for the maximum production of a-manosidase was evaluated by incubation at temperature $18,22,26,30,35,40$ and $45^{\circ} \mathrm{C}$. Cultures were incubated for $28 \mathrm{~d}$ at the required temperatures in an incubator cum orbital shaker set at $120 \mathrm{rpm}$.

\section{Optimization of agitation}

The optimal agitation speed (rpm) for the production of protonemal biomass and the maximum production of a-manosidase were evaluated by using $70,90,110,130,150,170$ and 190 rpm agitation. Samples were withdrawn after $28 \mathrm{~d}$ of incubation at $22^{\circ} \mathrm{C}$ on a rotary shaker set at $120 \mathrm{rpm}$.

\section{Effect of various carbon sources}

Carbon sources were screened to check their efficacy on the mannosidase enzyme production. $1 \% \mathrm{w} / \mathrm{v}$ of various carbon sources (dextrose, sucrose, lactose, xylose, maltose and galactose were used to check their effect on mannosidase production.

\section{Effect of various nitrogen sources}

Different nitrogen sources such as ammonium chloride, ammonium nitrate, potassium nitrate, ammonium phosphate and sodium nitrate $(1 \% \mathrm{w} / \mathrm{v})$ were screened to check their efficacy on amannosidase production.

\section{Statistical designTaguchi Design of experiment}

Based on our previous one factor at a time experiments five critical factors, namely sucrose (\%), ammonium nitrate $(\%)$, temperature $\left({ }^{\circ} \mathrm{C}\right)$, medium $\mathrm{pH}$ and agitation $(\mathrm{rpm})$ having a significant influence on protonemal biomass and enzyme production was chosen and were varied at four different levels in Taguchi design of experiments (Table 1). . The selected variables were arranged into an orthogonal array (L16 orthogonal array for the representative experiments. The L-16 orthogonal experimental design along with a-manosidase production values are presented in (Table 2). Qualitek-4 software (version 17.1.0, Nutek Inc., USA) for automatic design of experiments using the approach of Taguchi methodology was used in the present part of the study.

\section{Table 1 Selected process parameters and respective levels in the experimental design}




\begin{tabular}{|llllll|}
\hline SI. No & Factors & Level 1 & Level 2 & Level 3 & Level 4 \\
\hline 1 & Maltose \% (w/v) & 0.5 & 1 & 1.5 & 2 \\
\hline 2 & $\mathrm{NH}_{4} \mathrm{NO}_{3} \%(\mathrm{w} / \mathrm{v})$ & 0.5 & 1 & 1.5 & 2 \\
\hline 3 & Temperature $\left({ }^{\circ} \mathrm{C}\right)$ & 22 & 24 & 26 & 28 \\
\hline 4 & $\mathrm{pH}$ & 5.4 & 5.6 & 5.8 & 6 \\
\hline 5 & Agitation $(\mathrm{rpm})$ & 100 & 120 & 140 & 160 \\
\hline
\end{tabular}

Table $2 \mathrm{~L}-16$ Orthogonal array of Taguchi experimental design for a-mannosidase production from protonemal biomass of $H$. nymaniana

\begin{tabular}{|lllllll|}
\hline Run & Maltose & $\mathrm{NH}_{4} \mathrm{NO}_{3}$ & Temperature & $\mathrm{pH}$ & Agitation & $\begin{array}{l}\text { a-mannosidase } \\
(\mathrm{U} / \mathrm{ml})\end{array}$ \\
\hline 1 & $\mathrm{~L} 1$ & $\mathrm{~L} 1$ & $\mathrm{~L} 1$ & $\mathrm{~L} 1$ & $\mathrm{~L} 1$ & 7.8 \\
\hline 2 & $\mathrm{~L} 1$ & $\mathrm{~L} 2$ & $\mathrm{~L} 2$ & $\mathrm{~L} 2$ & $\mathrm{~L} 2$ & 9.2 \\
\hline 3 & $\mathrm{~L} 1$ & $\mathrm{~L} 3$ & $\mathrm{~L} 3$ & $\mathrm{~L} 3$ & $\mathrm{~L} 3$ & 10.9 \\
\hline 4 & $\mathrm{~L} 1$ & $\mathrm{~L} 4$ & $\mathrm{~L} 4$ & $\mathrm{~L} 4$ & $\mathrm{~L} 4$ & 8.5 \\
\hline 5 & $\mathrm{~L} 2$ & $\mathrm{~L} 1$ & $\mathrm{~L} 2$ & $\mathrm{~L} 3$ & $\mathrm{~L} 4$ & 9.2 \\
\hline 6 & $\mathrm{~L} 2$ & $\mathrm{~L} 2$ & $\mathrm{~L} 1$ & $\mathrm{~L} 4$ & $\mathrm{~L} 3$ & 8.5 \\
\hline 7 & $\mathrm{~L} 2$ & $\mathrm{~L} 3$ & $\mathrm{~L} 4$ & $\mathrm{~L} 1$ & $\mathrm{~L} 2$ & 11.5 \\
\hline 8 & $\mathrm{~L} 2$ & $\mathrm{~L} 4$ & $\mathrm{~L} 3$ & $\mathrm{~L} 2$ & $\mathrm{~L} 1$ & 4.5 \\
\hline 9 & $\mathrm{~L} 3$ & $\mathrm{~L} 1$ & $\mathrm{~L} 3$ & $\mathrm{~L} 4$ & $\mathrm{~L} 1$ & 10.2 \\
\hline 10 & $\mathrm{~L} 3$ & $\mathrm{~L} 2$ & $\mathrm{~L} 4$ & $\mathrm{~L} 3$ & $\mathrm{~L} 2$ & 9.5 \\
\hline 11 & $\mathrm{~L} 3$ & $\mathrm{~L} 3$ & $\mathrm{~L} 1$ & $\mathrm{~L} 2$ & $\mathrm{~L} 4$ & 11.8 \\
\hline 12 & $\mathrm{~L} 3$ & $\mathrm{~L} 4$ & $\mathrm{~L} 2$ & $\mathrm{~L} 1$ & $\mathrm{~L} 3$ & 12.5 \\
\hline 13 & $\mathrm{~L} 4$ & $\mathrm{~L} 1$ & $\mathrm{~L} 3$ & $\mathrm{~L} 2$ & $\mathrm{~L} 3$ & 7.9 \\
\hline 14 & $\mathrm{~L} 4$ & $\mathrm{~L} 2$ & $\mathrm{~L} 3$ & $\mathrm{~L} 1$ & $\mathrm{~L} 4$ & 9.4 \\
\hline 15 & $\mathrm{~L} 4$ & $\mathrm{~L} 3$ & $\mathrm{~L} 2$ & $\mathrm{~L} 4$ & $\mathrm{~L} 1$ & 9.2 \\
\hline 16 & $\mathrm{~L} 4$ & $\mathrm{~L} 4$ & $\mathrm{~L} 1$ & $\mathrm{~L} 3$ & $\mathrm{~L} 2$ & 7.8 \\
\hline
\end{tabular}




\section{Determination of protonemal biomass at different time period}

Optimum incubation period for a-mannosidase production determined by one variable-at-a-time method is depicted in Fig.1. Maximum growth of the protonemal biomass was observed in 28 days culture, thereafter no further noticeable increase in protonemal biomass observed with the increase in time period. Further, highest mannosidase activity recorded for 28 days old culture and no activity declined with the increase in culture time period.

\section{Screening of different culture parameters affecting enzyme production}

Various physical parameters such as culture period, temperature, $\mathrm{pH}$, agitation speed and nutritional parameters such as carbon and nitrogen sources were optimized using classical method and later the optimum level of each parameter was further optimized by Taguchi orthogonal array to predict the more accurate levels of each component on the basis of interaction studies.

\section{Optimization of initial pH of culture medium}

The $\mathrm{pH}$ of the culture medium influences biomass and enzyme production. Higher a-mannosidase, production was observed at pH 5.5. Production of a-mannosidase slowly declines after pH 6 (Fig. 2).

\section{Optimization of incubation temperature}

The production of a-mannosidase at different temperature is depicted in fig.3. Figure 3 reveals highest mannosidase activity at $26^{\circ} \mathrm{C}$. The enzyme activity declined slowly with the increase in temperature.

\section{Effect of agitation}

The a-manosidase activity improved with an increase in agitation speed up to $120 \mathrm{rpm}$ and further increase in agitation gave no noticeable improvement in it. Highest activity of the enzyme noticed in cultures incubated at $120 \mathrm{rpm}$ (fig. 4). Decrease in enzyme activity may be due to damage to protonemal biomass.

\section{Effect of different carbon sources}

Most potent carbon sources were selected by one factor at a time method. Almost every carbon sources tested, enhanced the mannosidase production, except xylose. Maltose exhibited higher mannosidase yield $(5.8 \mathrm{U} / \mathrm{ml})$ followed by dextrose $(4.8 \mathrm{U} / \mathrm{ml})$ as shown in Fig. 5 .

\section{Effect of different nitrogen sources}

Screening of the various nitrogen sources tested at $1 \% \mathrm{w} / \mathrm{v}$ level in the production medium revealed that most of the inorganic sources significantly enhanced the mannosidase production. Ammonium nitrate acted as a best nitrogen source with maximum activity of $8.2 \mathrm{U} / \mathrm{ml}$ followed by sodium nitrate Fig. 6 . 


\section{Evaluation of the factors affecting mannosidase productivity}

On the basis of the experiment carried out various process parameters were selected and respective levels in the experimental design were considered. Sixteen different trial conditions were used for the analysis of suspension culture parameters and identifying optimum levels of proposed factors (Fig. 7). The averages of mannosidase activity for the different trials (experimental) together with the predicted activity are shown in table 3. Optimization was done on the basis of the results of these 16 experimental trials. Moreover, after optimizing all these production parameters in 16 trial conditions it has been analyzed that different factors affect the enzyme production at different levels. The favorable levels of different factors can be evaluated from the value of severity index (SI). The SI value gives idea about the interaction between two factors which may help us in understanding of overall process of analysis. The SI value of $100 \%$ indicates a $90^{\circ}$ angle between the lines versus $0 \% \mathrm{SI}$ for parallel lines. The estimated interaction severity index of the factors under study is given in Table 3 . After the consideration of $\mathrm{SI}$ it has been observed that the $\mathrm{pH}$ and RPM has maximum effect on amannosidase production while temperature and RPM has the minimum. Rest of the factors has intermediate effect on enzyme production. Different factors at their best levels and their respective contributions are mentioned in table 4.

Table 3 Estimated interactions between the factors for mannosidase production

\begin{tabular}{|c|c|c|c|c|c|}
\hline SI. No & $\begin{array}{l}\text { Interacting Factor Pairs } \\
\text { (Order based on SI) }\end{array}$ & Columns & Severity Index (SI \%) & Col & Optimum \\
\hline 1 & $\mathrm{pH} \times \mathrm{RPM}$ & $4 \times 5$ & 64.20 & 1 & {$[2,1]$} \\
\hline 2 & Temperature $\times \mathrm{pH}$ & $3 \times 4$ & 37.68 & 7 & {$[3,2]$} \\
\hline 3 & Maltose $\times \mathrm{pH}$ & $1 \times 4$ & 35.79 & 5 & {$[2,2]$} \\
\hline 4 & $\mathrm{NH}_{4} \mathrm{NO}_{3} \times \mathrm{pH}$ & $2 \times 4$ & 30.06 & 6 & {$[4,2]$} \\
\hline 5 & Maltose $\times \mathrm{NH}_{4} \mathrm{NO}_{3}$ & $1 \times 2$ & 18.25 & 3 & {$[2,4]$} \\
\hline 6 & Maltose $\times$ RPM & $1 \times 5$ & 14.90 & 4 & {$[2,1]$} \\
\hline 7 & $\mathrm{NH}_{4} \mathrm{NO}_{3} \times \mathrm{RPM}$ & $2 \times 5$ & 14.55 & 7 & {$[4,1]$} \\
\hline 8 & $\mathrm{NH}_{4} \mathrm{NO}_{3} \times$ Temperature & $2 \times 3$ & 8.13 & 1 & {$[4,3]$} \\
\hline 9 & Maltose $\times$ Temperature & $1 \times 3$ & 2.63 & 2 & {$[2,3]$} \\
\hline 10 & Temperature $\times$ RPM & $3 \times 4$ & 0.94 & 6 & {$[3,1]$} \\
\hline
\end{tabular}


Table 4 Four different levels of factors selected for enzyme production and their contribution

\begin{tabular}{|c|c|c|c|c|}
\hline SI. No & Factors & Level Description & Optimum Level & Contribution \\
\hline 1 & Maltose & 1.5 & 2 & 1.033 \\
\hline 2 & $\mathrm{NH}_{4} \mathrm{NO}_{3}$ & 2.0 & 4 & 2.076 \\
\hline 3 & $\mathrm{pH}$ & 5.8 & 3 & 0.976 \\
\hline 4 & Temperature & $26^{\circ} \mathrm{C}$ & 3 & 1.151 \\
\hline 5 & RPM & 120 & 3 & 1.135 \\
\hline \multicolumn{4}{|c|}{ Total contribution from all factors } & 6.370 \\
\hline \multicolumn{4}{|c|}{ Current grand average of performance } & 8.298 \\
\hline \multicolumn{4}{|c|}{ Expected result at optimum condition } & 14.669 \\
\hline
\end{tabular}

\section{Optimum conditions and validation of experiments based on ANOVA}

The significance and percentage contribution of factors on a-manosidase production variation has been determined from ANOVA (Analysis of variance). From the calculated ratios (F) of all selected parameters, it was noticed that all factors and their interactions considered in the experimental design were statistically significant at $95 \%$ confidence limit, indicating that nearly all the variability of experimental data for a-manosidase production can be explained in terms of significant effects. ANOVA reports along with the percentage of contribution of each factor are shown in Table 5. Results indicated that $\mathrm{NH}_{4} \mathrm{NO}_{3}$ contributed the maximum impact (39.6 \%) on mannosidase activity followed by temperature (19.9\%) and pH (16.09\%), RPM (11.46\%) and maltose (11\%). Significant contribution of each factor in a-mannosidase activity is depicted in Fig. 8. Individually each factor influenced the enzyme activity at a certain level. However, this significant factor gives maximum yield when these factors act collectively, which may be due to the interactive effect of different factors. The a mannosidase activity estimated statistically showed the $13.6 \mathrm{U} / \mathrm{ml}$ of enzymatic activity and there was around $63 \%$ increase in the production level after optimization of the culture parameters through Taguchi DOE method (Fig. 9)

Table 5 Analysis of variance of the factors in Step 1 using average of results 


\begin{tabular}{|llrllccc|}
\hline S. No & Factors & $\begin{array}{l}\text { DOF } \\
\text { (f) }\end{array}$ & Sum of Square & Variance & F ratio & Pure sum & $\begin{array}{l}\text { Percent } \\
\text { P\% }\end{array}$ \\
\hline 1 & Maltose & 3 & 15.504 & 5.168 & 505.014 & 73.644 & 11.354 \\
\hline 2 & $\mathrm{NH}_{4} \mathrm{NO}_{3}$ & 3 & 53.564 & 17.854 & 25.707 & 254.422 & 39.612 \\
\hline 3 & Temperature & 3 & 27.078 & 9.026 & 75.031 & 128.616 & 19.947 \\
\hline 4 & $\mathrm{pH}$ & 3 & 21.773 & 7.257 & 25.395 & 103.42 & 16.009 \\
\hline 5 & $\mathrm{RPM}$ & 3 & 15.647 & 5.214 & 51.962 & 74.32 & 11.460 \\
\hline Error & & 16 & 1.122 & 0.07 & & & $1.618 \%$ \\
\hline Total & & 31 & 134.695 & & & & $100 \%$ \\
\hline
\end{tabular}

\section{Discussion}

\section{a-mannosidase production}

Bryophytes have emerged as a promising biopharming tool for theassembly of complex biopharmaceuticals. Literature data reveals the assembly production of plant-based production systems is gaining importance over the last years. Today different plant systems are being explored to successfully grow them in axenic culture conditions so as to satisfy the demand of the biopharmaceutical industry. Although attempts are being made for the successful establishment of suspension culture from different bryophytes species only a few very few Atrichum undulatum (Ono et al., 1987), peat moss Sphagnum imbrications (Kajita et al., 1987) are attempted for the establishment of cell suspension culture from mosses. However, attempts for the establishment of a suspension culture system in mosses have gain momentum with the successful establishment of bioreactor based suspension culture of moss Physcomitrella patens (Decker and Reski., 2007; Paul and Ma .,2011., Paul et al., 2013) for the production of biopharmaceuticals. Within the the present study, we endeavor to establishment the suspension culture of the moss $H$. nymaniana by optimizing the culture parameters by conventional and statistical methods.

\section{Preliminary screening of nutrients and physical factors for statistical optimization}

The nutrient medium plays a big role in enzyme production and biomass formation within the biological production system. Several reports are available showing an enhanced enzyme production under optimized medium conditions (Suzuki et al., 1976; Prakasham et al., 2005). Various physical parameters such as culture period, temperature, $\mathrm{pH}$, agitation speed, and nutritional parameters like carbon and nitrogen sources were optimized using the classical method. Incubation temperature plays a pivotal role in enzyme and biomass production. The optimum temperature and $\mathrm{pH}$ for enzyme production usually 
vary from one organism to a different (Banargee and Bhattacharya, 1992; Kumar and Takagi, 1999). Based upon this concept, the role of incubation temperature and $\mathrm{pH}$ on a-mannosidase production by protonema culture of H. nymaniana was studied at different temperatures such as 18, 22, 26, 28 and 30, ${ }^{\circ} \mathrm{C}$ and $\mathrm{pH}(4,4.5,5,5.5,6.0,6.5$ and 7.0). The outmost enzyme production of a-mannosidase was observed at a temperature of $26^{\circ} \mathrm{C} \mathrm{pH}$ and 5. Production of a-mannosidase slowly declines after $\mathrm{pH} 6$. Agitation speed has an influential role within the growth of protonemal cells of $H$. nymaniana and enzyme production. The activity of the enzyme improved considerably with a rise in agitation speed up to $120 \mathrm{rpm}$ while an extra rise in RPM didn't show any any noticeable change in enzyme activity as well as biomass production. A decrease in enzyme activities probably could be due to the disruption of the protonemal tissues at high agitation. Although in contrast to the present Decker and Reski (2007) recorded a rather a higher agitation speed of $150 \mathrm{rpm}$ within the culture of Physcomitrella patens for biomass production. Further, among all the supplementary carbon sources $(1 \% \mathrm{w} / \mathrm{v})$, maltose has been found to be the best source for mannosidase enzyme production. Out of the various $t$ nitrogen sources tested above NH4NO3 supported the outmost enzyme production $(8.2 \mathrm{U} / \mathrm{ml})$. This result was supported by the previous finding of alpha-mannosidase production from Penicilliumoxalicum KUB-SN2-1 where yeast extract and NH4NO3 showed maximum enzyme activity Chantron et al., 2012.

\section{Taguchi Design of experiment}

Initial screening of the culture parameters affecting enzyme production was conducted by the OFAT method later all factors were optimized that control the enzyme production process by the Taguchi DOE method. This Taguchi approach of DOE involves a easy methodology that selects the best conditions for the enzyme production. Various statistical methods are for the optimization of production of the enzyme in various studies (Azin et al., 2007, Adnani et al., 2010, Shehata and Abeer, 2014, Aishwarya et al., 2017), but to our knowledge, no investigation has been reported to explain the sequential optimization process of the various factors for the production of the enzyme from the moss $H$. nymaniana. The enzyme production before optimization, was $8.3 \mathrm{U} / \mathrm{ml}$, and an increase of 2 fold enzyme production was achieved after the optimization process by the Taguchi DOE method. The anticipated maximum mannosidase enzyme production was estimated to be $14.66 \mathrm{U} / \mathrm{ml}$. Experiments conducted in triplicates to validate the experimental design, in optimized conditions, revealed $13.6 \mathrm{U} / \mathrm{ml}$ a-mannosidase activity. This experimental value $(14.26 \mathrm{U} / \mathrm{ml})$ is in good agreement there upon of the anticipated the value that validates the model design.

\section{Optimization and validation}

Three independent experiments were conducted for validation of the anticipated results under optimized conditions. In this model, the experimental mannosidase activity of $14.26 \mathrm{U} / \mathrm{ml}$ was obtained which correlated to the predicted activity $(14.66 \mathrm{U} / \mathrm{ml})$ confirming the rationality of the model. This is 2 fold higher than that obtained before optimization. Thus, an overall 2 fold increase in mannosidase activity was observed after optimization. 


\section{Conclusion}

a-mannosidases are important $\mathrm{N}$-glycosylation enzymes utilized in in the pharmaceutical industry therefore its production during a large scale is of paramount importance. Till now various literature conveys the production of a-mannosidase from different animal and plant sources. But no report for the production of the enzyme from moss suspension culture reported till date. Within the present study, both classical and statistical methods were used to evaluate the effect of the variables for the increased production of a-mannosidase from moss $H$. nymaniana. Taguchi experimental design with L16 orthogonal array was proved to be completely unique and effective method for enhancing amannosidase production. It has been observed that $\mathrm{NH}_{4} \mathrm{NO}_{3}$ features a a maximum effect on enzyme production while maltose and RPM have minimum effect on the suspension culture of moss $H$. nymaniana. The a-mannosidase activity estimated statistically showed the $13.6 \mathrm{U} / \mathrm{ml}$ of enzymatic activity and there was a 2-fold increase within the production level after optimization of the culture parameters through the Taguchi DOE method.

\section{List Of Abbreviations}

ANOVA: Analysis of variance; DOE: Design of experiment; $\mathrm{NH}_{4} \mathrm{NO}_{3}$ : Ammonium nitrate, $\mathrm{pH}$ : potential hydrogen; RPM : Rotation per minute; SI: Severity index

\section{Declarations}

\section{Funding}

This work did not receive funding from any organization or institution

\section{Competing interests}

The authors declare that they have no competing interests

\section{Availability of Data and material}

The datasets used and/or analyzed during the current study available from the corresponding author on reasonable request

\section{Ethics approval and consent to participate}

Not applicable

\section{Consent for publication}

Not applicable

\section{Authors contribution}


MR conducted all the experiment and wrote the manuscript. CR helped in manuscript editing and data analysis. All the authors have read and approved the manuscript.

\section{Acknowledgements}

Authors are also thankful to Birla Institute of Technology, Department of Bioengineering and Centre of Excellence (COE) TEQUIP phase II for providing laboratory facilities and infrastructure support.

\section{References}

1. Abdel-Fattah YR, Saeed HM, Gohar YM, El-Baz MA (2005) Improved production of Pseudomonas aeruginosa uricase by optimization of process parameters through statistical experimental designs. Process Biochemistry 40: 1707e1714.

2. Akino T, Nakamura N, Horikoshi K (1988) Characterization of three a-mannanases of an alkalophylic Bacillus sp. Agric. Biol. Chem. 52: 773-779.

3. Adnani A, Basri M, Malek EA, Salleh AB, Abdul Rahman MB, Chaibaksh N et. al (2010) Optimization of lipase-catalyzed synthesis of xylitol ester by Taguchi robust design method. Ind Crop and Prod. 31(2):350-356.

4. Azin M, Moravez R, Zareh D (2007) Production of xylanase by Trichoderma longibrachiatumon a mixture of wheat bran and wheat straw: Optimization of culture condition by Taguchi method. Enzyme Microbe Technol. 40(4): 801-805.

5. Banargee R, Bhattacharya BC: Extracellular alkanine protease of newly isolated Rhizopus oryzae. Biotechnol let 1992 14:301-304.

6. Basak B, Bhunia B, Dutta S, Dey A (2013a) Enhanced biodegradation of 4-chlorophenol by Candida tropicalis PHB5 via optimization of physicochemical parameters using Taguchi orthogonal array approach. Int Biodeteriorat Biodegrad 78:17-23

7. Basile, D. V. 1975. A comparison of macronutrient media used to culture bryophytes. Bryologist. 78: 403-413

8. Basak B, Bhunia B, Mukherjee S, Dey A (2013b) Optimization of physicochemical parameters for phenol biodegradation by Candida tropicalis PHB5 using Taguchi methodology. Desalin Water Treat 51:6846-6862

9. Beg Q K, Sahai V, Gupta R (2003) Statistical media optimization and alkaline protease production from Bacillus mojavensisin a Process Biochem. 39: 203 -209.

10. Chethamaraskshan A, Parambayil N, Miziria N, Souyma PS, Lakshmi Kiran MS, Ramgopal A, Dileep A, Nambisan P (2017) Optimization of laccase production from Marasmiellus palmivorusLA1 by Taguchi method of Design of experiments. BMC Biotech 17(12) 4015

11. Chantron ST, Buengsrisawat K, Pokaseam A, Sombat T, Dangrampuram P et al., Optimization of extracellular mannanase production from Penicillium oxalicum KUB-SN2-1 and application for hydrolysis property. J Sci Technol 35 (1): 17-22. 
12. Chin LH, Ali ZM, Lazan H (1999) Cell wall modifications, degrading enzymes and softening of 239 carambola fruit during ripening. J Exp Bot 50: 767-775.

13. Christgau S, Andersen LN, Kauppinen S, Heldt-hansen HP, Dalboege, H (1994) Purified enzyme exhibiting mannanase activity; application in oil, paper, pulp, fruit and vegetable juice industry and carrageenan extraction. Patent Novo-Nordisk, 942557610 November 1994.

14. Decker EL, Reski (2007) Moss bioreactors producing improved biopharmaceuticals. Current openion Biotechnol 18(5): 393-398.

15. Decker EL, Reski R, (2008) Current achievements in the production of complex biopharmaceuticals with moss bioreactors. Bioprocess and Biosyst Eng. 31: 3-9.

16. Deniz F( 2013) Optimization of methyl orange bioremoval by Prunus amygdalus (almond) shell waste:Taguchi methodology approach and biosorption system design, Desalin. Water Treat. 51: 7067-7073.

17. Dutta S, Basak B, Bhunia B, Dey A (2014b) Bioprocess engineering aspects of Rapamycin (Sirolimus) roduction: a review on past achievements and recent perspectives. J Bioprocess Eng Biorefin 3:243256

18. Forsee WT, Palmer CF, Schutzbach JS (1989) Purification and characterization of an a-1,2mannosidase involved in processing asparagines-linked oligosaccharides. J Biol Chem 264: 38693876.

19. Hohe A, Reski R (2002) Optimisation of a bioreactor culture of the moss Physcomitrella patents for mass production of protoplasts. Plant Science. 163: 69-74.

20. Hossain MA, Nakano R, Nakamura K, Hossain MT, Kimura Y, (2010) Molecular characterization of plant acidic alpha-mannosidase, a member of glycosylhydrolase family 38 , involved in the turnover of $\mathrm{N}$-glycans during tomato fruit ripening. J Biochem 148: 603-616.

21. Jacob GS, Scudder P (1994) Glycosidases in structural analysis. Methods Enzymol. 230: 280-299.

22. Kajita M, Takio S, Takami S, Hino S (1987) Establishment and growth characterization of suspension culture of cells from the moss, Sphagnum imbrication. Physiol Plant 70: 21-26.

23. Kennedy M, Krouse D (1999) Strategies for improving fermentation medium performance: a review. J Ind Microbiol Biotechnol 23:456-475

24. Kestwal RM, Bhide SV (2005) Purification and partial characterization of alpha-D-mannosidase from Erythrina indica Indian J Biochem Biophys 42:156-60.

25. Kobata A (1979) Use of endo-and exoglycosidases for structural studies of glycoconjugates. Anal Biochem 100: 1-14.

26. Kumar CG, Takagi H: Microbial alkaline protease: from a bioindusrtial viewpoint . Biotechnol Adv 1999, 17(7): 561-594.

27. Lowry OH, Rosebrough NJ, Farr AL, Randall RJ (1951) Protein measurement with the Folin phenol reagent. J Biol Chem 193:265-275 
28. Lowry OH, Rosebrough NJ, Farr AL, Randall RJ (1951) Protein measurement with the Folin phenolreagent. J Biol Chem 193:265-275.

29. Mohapatra N, Das SK ( 2009) Effect of process parameters and optimization on microwave puffing performance in rice. Res J Chem Environ 15 (2): 454-461.

30. Nankai H, Hashimoto W, Murata K (2002) Molecular Identification of Family 38-Mannosidase of Bacillus Strain GL1, Responsible for Complete Depolymerization of Xanthan, Appl Environ Microbiol 68:2731-2736.

31. Ono K, Murasaki Y(1988) Introduction and morphogenesis of cultured cells of bryophytes. J Hattori Bot lab 65:395-401.

32. Ono K, Murasaki Y, Kawaunchi K (1987) Establishment and characteristics of a cell suspension culture from a moss, Atrichum undulatum. The Botanical magazine. 100(2): 217-221.

33. Parekh S, Vinci V, Strobel R (2000) Improvement of microbial strains and fermentation processes. Appl Microbiol Biotechnol 54:287-301

34. Pastuszak I, Kaushal GP, Wall KA, Pan YT, Sturm A, Elbein AD (1990) Purification and properties of arylmannosidases from mung bean seedlings and soybean cells. Glycobiol. 1: 71-82.

35. Paul M, Ma JKC (2011). Plant-made pharmaceuticals: leading products and production platforms. Appl Biochem 58: 58-67.

36. Paul MJ, Teh AY, Twyman RM, Ma JK (2013) Target product selection-where can molecular pharming make the difference? Curr Pharm Des 19: 5478-5485.

37. Prasad K, Mohan S, Rao R, Pati B, Sarma P (2005) Laccase production by Pleurotusostreatus 1804: optimization of submerged culture conditions by Taguchi DOE methodology. Biochem Eng J 24:1726

38. Prasad KK, Mohan SV, Rao RS, Pati BR. Sarma PN( 2005) Laccase production by Pleurotus ostreatus 1804: optimization of submerged culture conditions by Taguchi DOE methodology. Biochemical Engineering Journal 24: 17e26.

39. ReyhaniF, RekabdarM, HemmatiA, SafeKordi A, Ahmadi (2013) Optimization of conditions in ultrafiltration treatment of produced water by polymeric membrane using Taguchi approach, Desalin. Water Treat. 51: 7499-7508.

40. Shehata AN , Abd El Aty AA (2014) Optimization of Process Parameters by Statistical Experimental Designs for the Production of Naringinase Enzyme by Marine Fungi. Int. J. Chem. Eng. 2014.

41. Sun $H$, Wofe JH( 2001) Recent progress in lysosomal a-mannosidase and its deficiency. Exp Mol Med $33(1): 1-17$.

42. Woo KK, Kimura Y (2005). Regulation of substrate specificity of plant a-mannosidase by cobalt ion: in vitro hydrolysis of high-mannose type $\mathrm{N}$-glycans by $\mathrm{Co}^{2+}$ activated Ginkgo a-mannosidase. Biosci Biotechnol Biochem 69: 1111-1119.

\section{Figures}




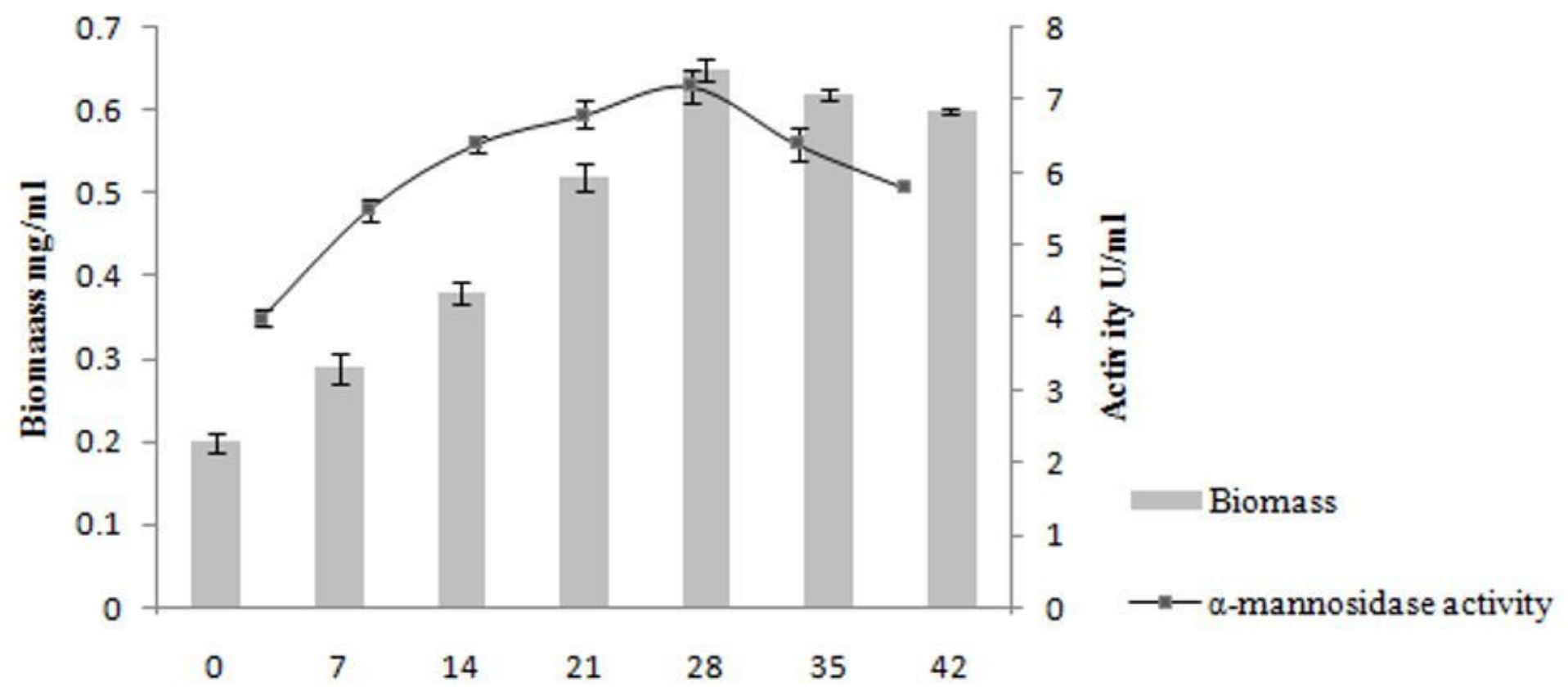

Figure 1

Effect of protonemal growth on a-mannosidase production in $\mathrm{H}$. nymaniana

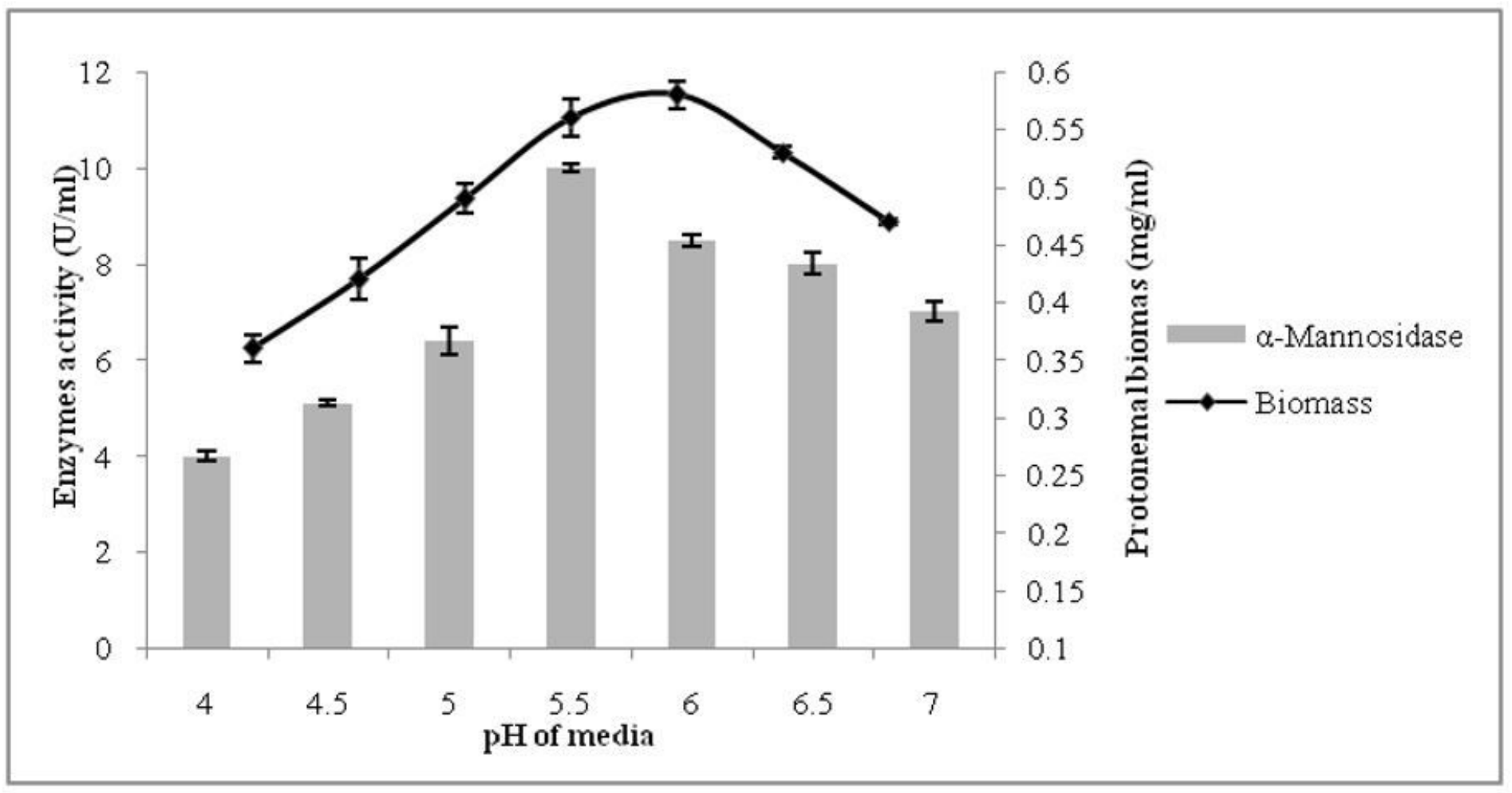

Figure 2

Effect of $\mathrm{pH}$ on a-mannosidase with respect to protonemal biomass of $\mathrm{H}$. nymaniana 


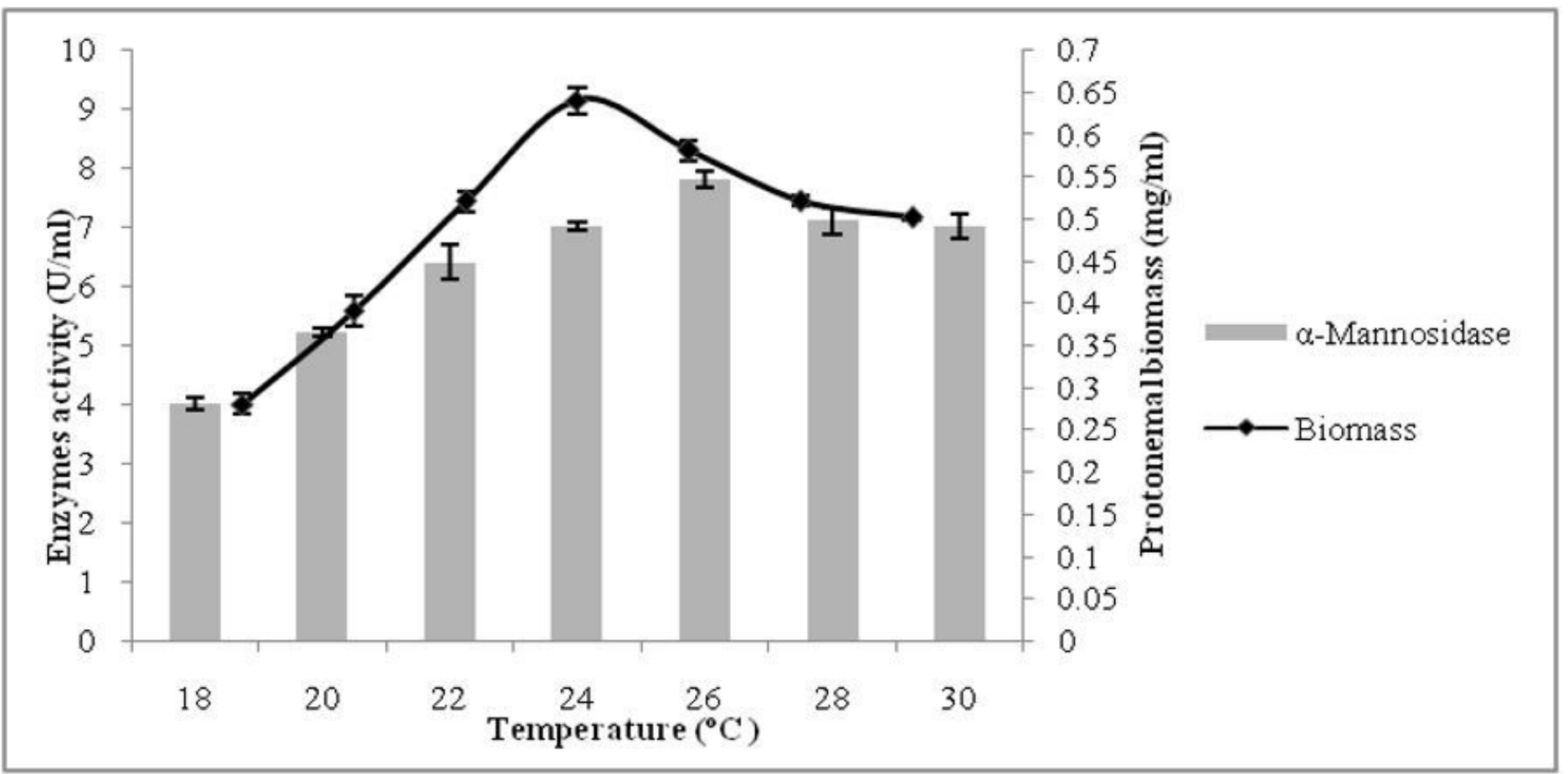

Figure 3

Effect of temperature on a-mannosidase with respect to protonemal biomass of $\mathrm{H}$. nymaniana

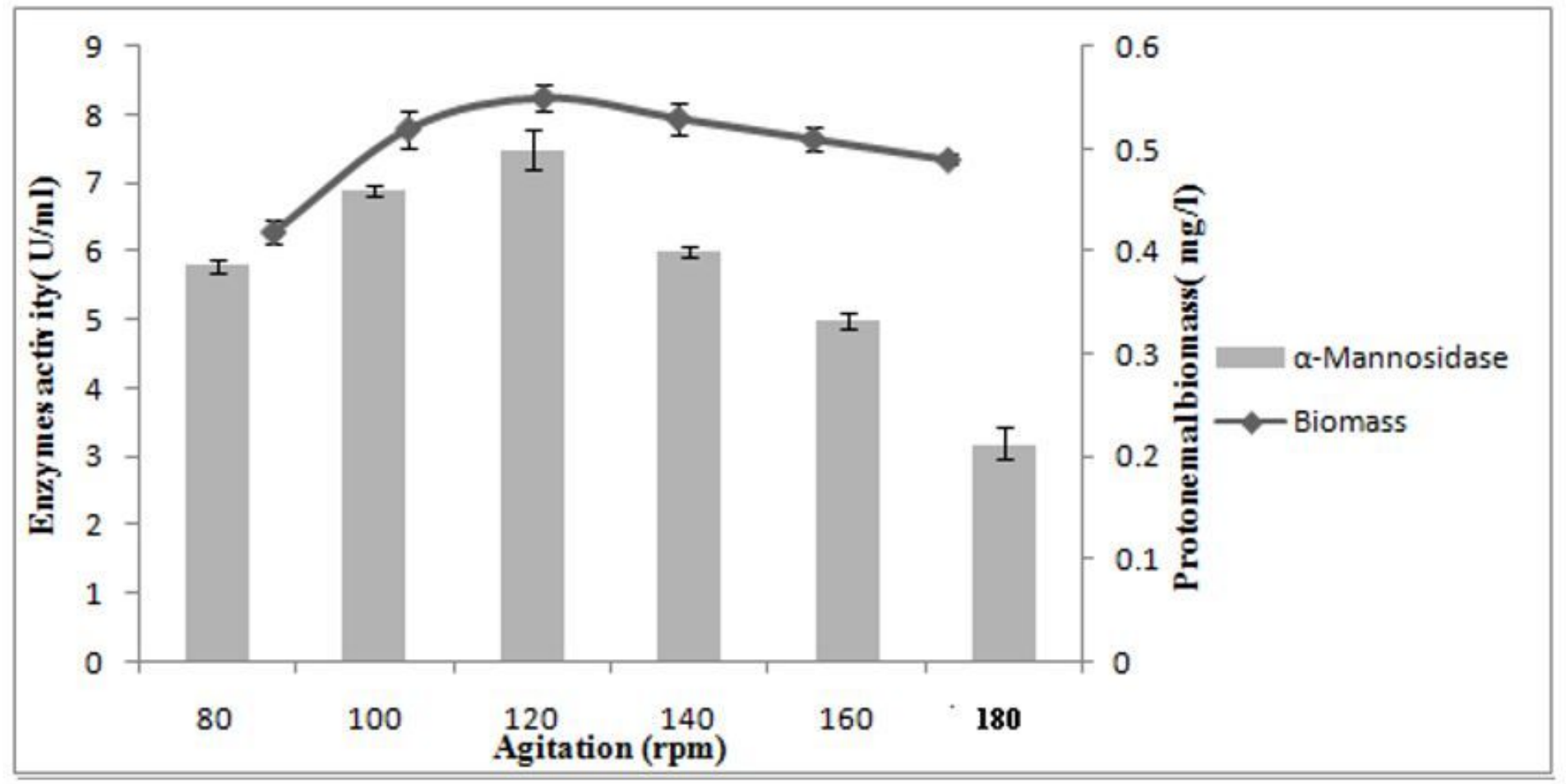

Figure 4

Effect of agitation on a-mannosidase with respect to protonemal biomass of $\mathrm{H}$. nymaniana 


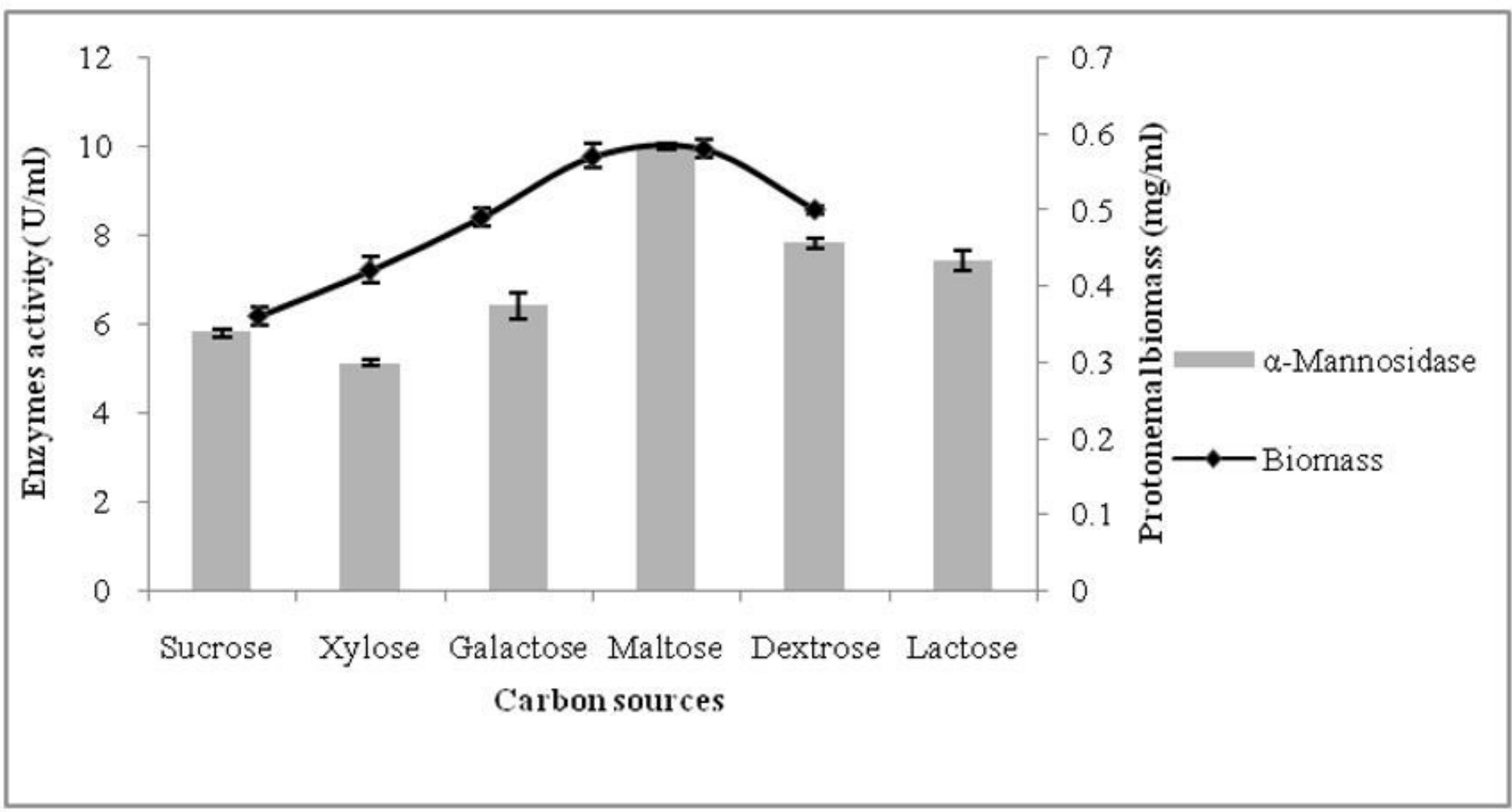

\section{Figure 5}

Effect of carbon source on a-mannosidase with respect to protonemal biomass of H. nymaniana

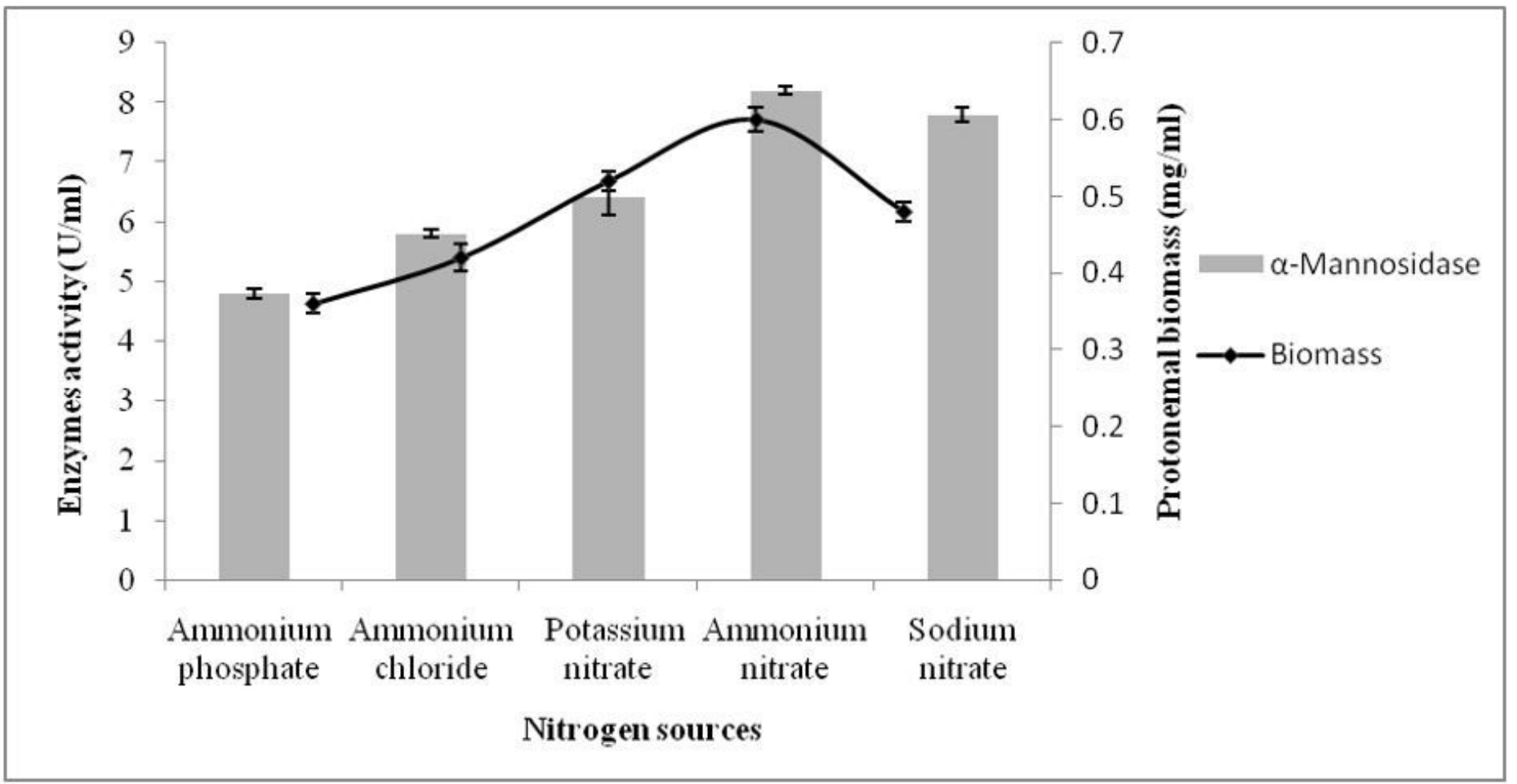

Figure 6 
Effect of nitrogen source on a-mannosidase with respect to protonemal biomass of $\mathrm{H}$. nymaniana

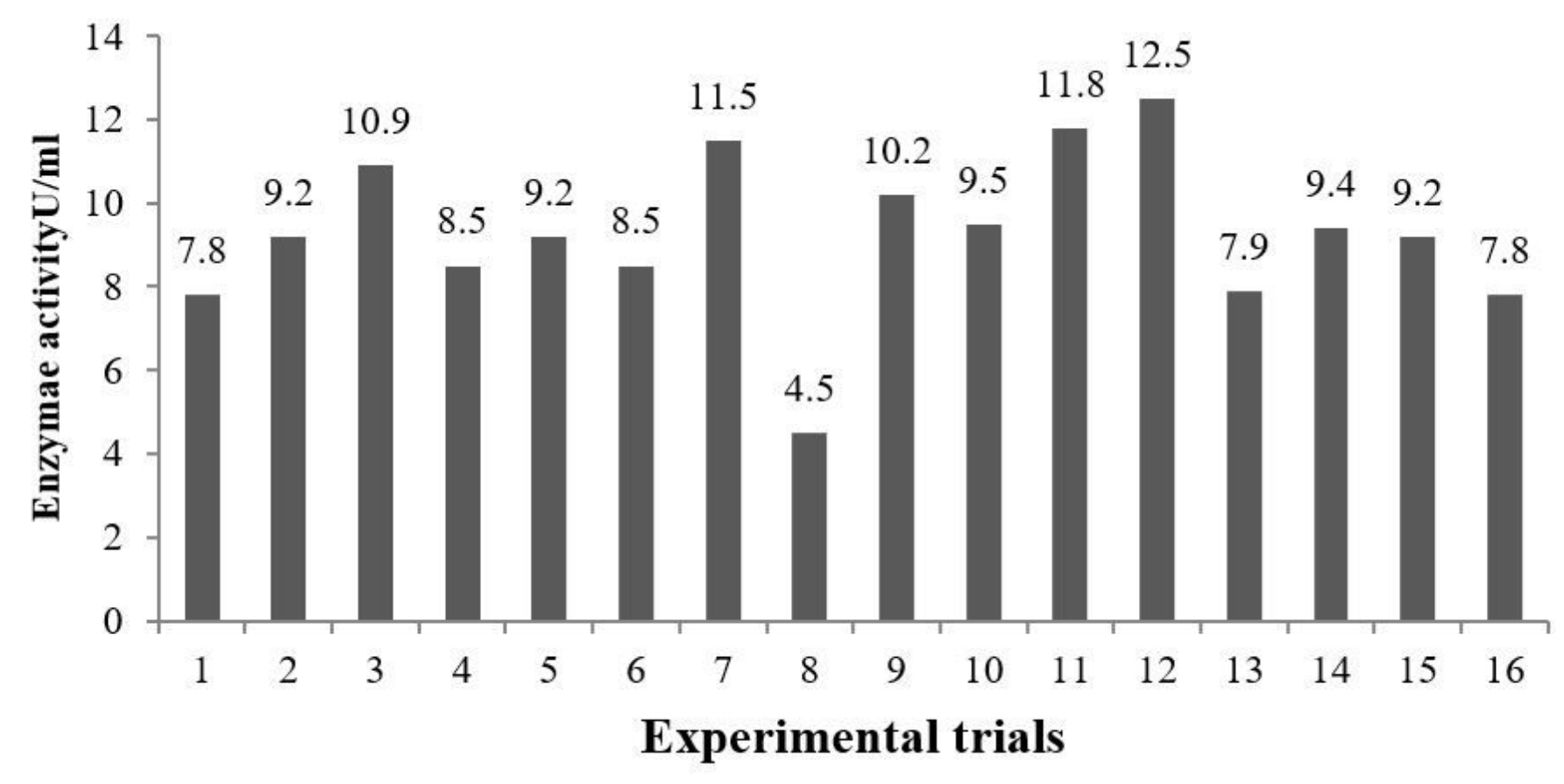

Figure 7

Enzyme activity on 16 trial conditions 


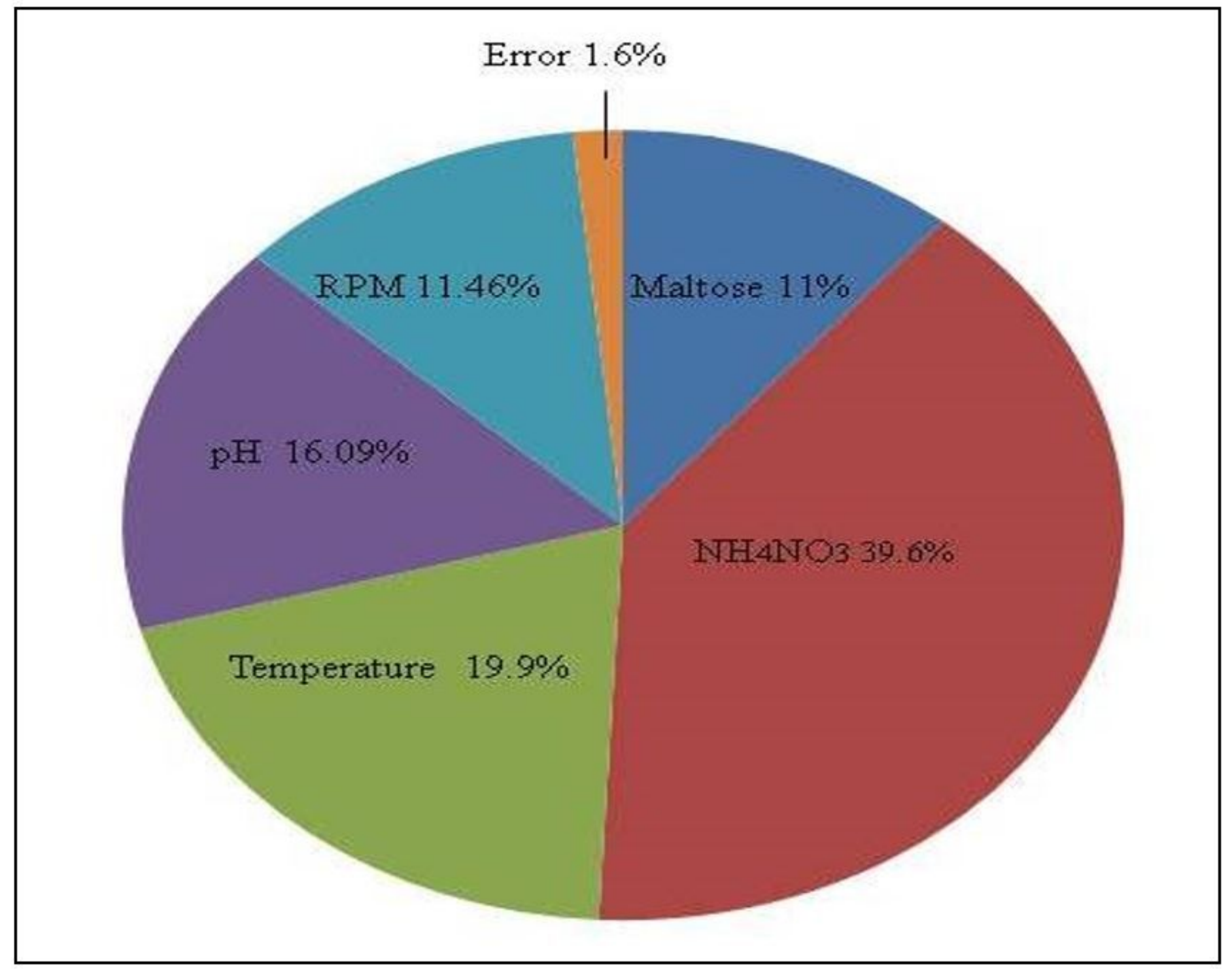

Figure 8

Percentage of various factors contributing to overall performances 


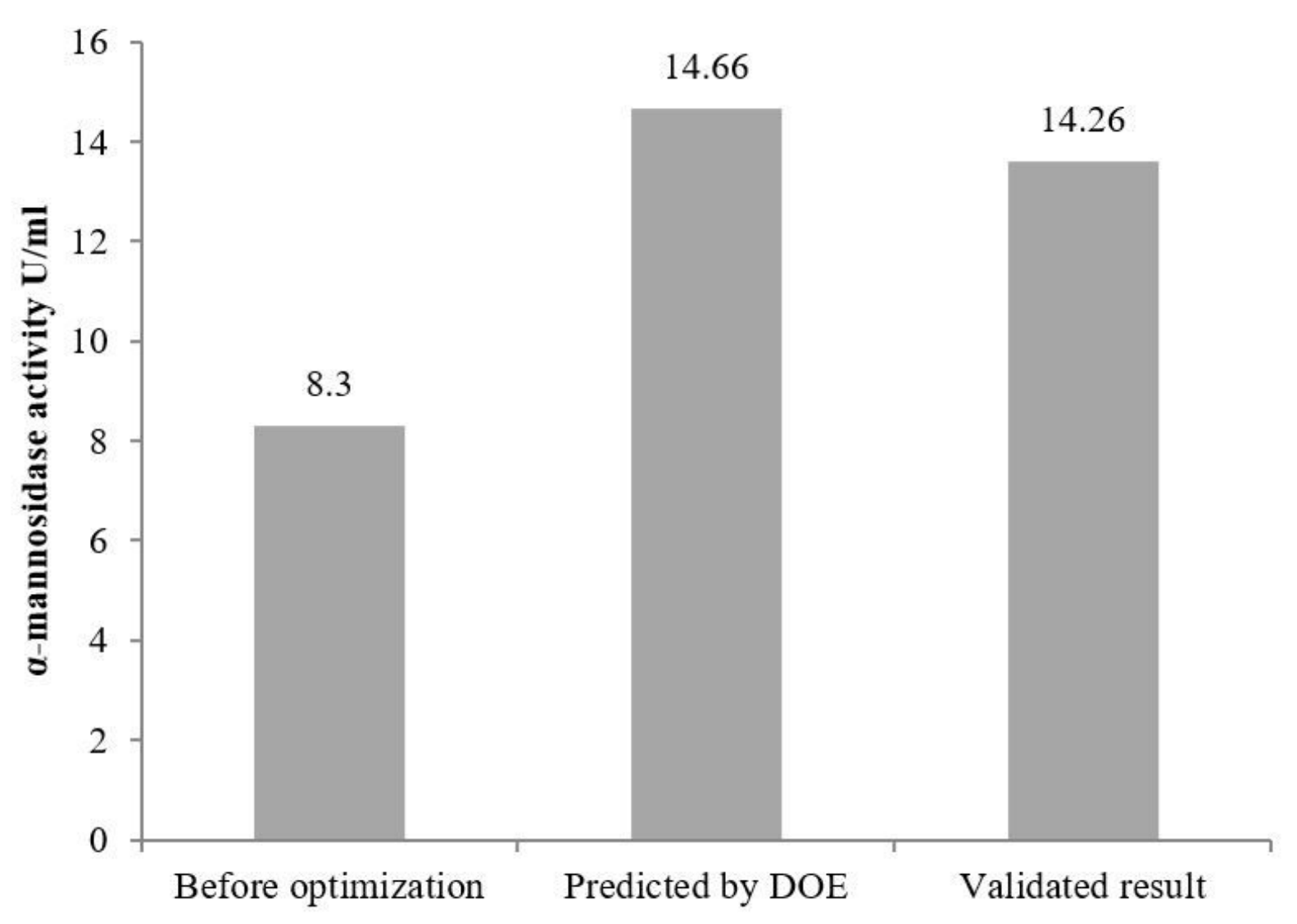

Figure 9

Comparison of enzyme activity before and after optimization process

\section{Supplementary Files}

This is a list of supplementary files associated with this preprint. Click to download.

- graphicalabstract.docx 